\title{
. \\ ДО ПИТАННЯ ПРО ПРИЕДНАННЯ УКРАЇНИ ДО РИМСЬКОГО СТАТУТУ МІЖНАРОДНОГО КРИМІНАЛЬНОГО СУДУ: ТЕОРЕТИЧНІ І ПРАКТИЧНІ АСПЕКТИ
}

\author{
ПИЛИПЕНКО Володимир Пилипович - кандидат юридичних наук, \\ заслужений юрист України, член Свропейської комісії «За демократію через \\ право» (2013-2017 рр.)
}

DOI:10.32782/NP.2020.2.2

\begin{abstract}
В статье исследуются теоретические u практические вопросъ в контексте присоединения Украинь к Римскому статуту Международного уголовного суда. Особое внимание уделяется анализу Заключения Конституционного Суда Украинъ от 11 июля 2001 года о соответствии Римского статута Конститущии Украинъ; сущности приниипа комплиментарности, который закреплен в Статуте; анализируются доктринальнъле подходь некоторых отечественных юристовмеждународников по вопросу присоединения Украинъ к Римскому статуту.

Ключевъе слова: Римский статут Международного уголовного суда, Международнъий уголовный суд, имплементация, военнъие преступления, Заключение Конституционного Суда Украинъ, принцип комплиментарности $u \partial p$.
\end{abstract}

Постановка проблеми

Найбільш дискусійним питанням наразі було і залишається зволікання з боку органів державної влади України ратифікація Римського Статуту Міжнародного кримінального суду (далі - Статуту МКС, Статут). Як відомо, Статут визначає чотири види міжнародних злочинів, що підпадають під юрисдикцію МКС: геноцид, злочини проти людяності, воєнні злочини та злочини агресії.

Питання визнання юрисдикції Міжнародного кримінального суду (далі - МКС) постало 3 новою силою після ратифікації Україною 16.09.2014 р. Угоди про асоціацію між Україною, з одного боку, та Європейським Союзом, Європейським співтовариством $з$ атомної енергії та їхніми державами-членами, з іншого боку [16] (далі - Угода про асоціацію). Відповідно до ст. 8 Угоди про асоціацію [16], Україна взяла на себе зобов'язання ратифікувати та імплементувати в національне законодавство Римський статут МКС, а також пов'язані з ним документи. СС визнає важливість МКС як гарантії дотримання прав та свобод людини, що підтверджується таким фактом: усі держави-члени GС визнали юрисдикцію МКС та ратифікували Римський статут.

Як відомо, з метою виконання зобов'язань за міжнародним правом 02.06.2016 р. Верховною Радою України були схвалено Закон «Про внесення змін до Конституції України (щодо правосуддя)» [13], відповідно до якого статтю 124 Конституції було доповнено частиною 6 такого змісту: «Україна може визнати юрисдикцію Міжнародного кримінального суду на умовах, визначених Римським статутом Міжнародного кримінального суду».

Згідно 3 висновком Венеціанської комісії від 26.10.2015 р. (висновок стосувався проекту цього Закону), таке формулювання статті Конституції отримало позитивний відгук. Однак з незрозумілих та юридично необгрунтованих причин це положення набирає чинності через три роки з дня опублікування закону, тобто з 30.06.2019 року. Зауважимо, що цей термін уже давно минув, а активізації у цьому напрямку з боку органів 


\section{Теорія, історія держави і права, конституційне право}

державної влади й дотепер не спостерігається.

Отже, метою цієї статті є дослідити теоретичні і практичні аспекти в контексті подолання перешкод щодо приєднання України до Статуту МКС.

\section{Аналіз останніх публікацій і досліджень}

Питання створення, функціонування та імплементації положень Статуту МКС досліджувались такими вітчизняними вченими, як: В.Ф. Антипенко, В.А. Базов,М. В. Буроменський, М.М. Гнатовський,Н.В. Дрьоміна, Н.А. Зелінська, О.В. Касинюк, А.О. Кориневич, І.О. Колотуха,В.М. Аисик, А. С. Мацко, В. М. Репецький, В.П. Попович, М.І. Хавронюк, В.Х. Ярмакі та ін.

\section{Виклад основного матеріалу}

Щодо ситуації, яка склалась навколо ратифікації Статуту МКС, доцільно надати деякі коментарі.

Слід зазначити, що проблема щодо ратифікації Статуту МКС не $є$ новою для України, адже вона виникла ще у 2000-2001 роках. Варто нагадати, що наша держава брала активну участь у розробці проєкту та прийнятті Статуту, зокрема українська делегація була учасником Дипломатичної конференції 15 червня - 17 липня 1998 року у Римі, на якій було прийнято Римський статут [5,c. 12], який був підписаний Україною 20 січня 2000 року, причому будь-яких застережень з боку нашої держави до тексту Статуту на момент підписання не виникало. Отже, очікувалось, що процес ратифікації Статуту не викличе непорозумінь. Однак Римський статут не був ратифікований у зв'язку з прийняттям Висновку Конституційного Суду України від 11 липня 2001 року №3-в/2001 [1] (далі - Висновок КСУ). Нагадаємо, що на підставі ст. 151 Конституції України, Президент України звернувся до Конституційного Суду України з клопотанням дати Висновок про відповідність Cтатуту Конституиї Украӥни, зокрема з питань:

- екстрадиції громадян та позбавлення імунітету посадових осіб у конституцій- ному поданні Президента України

про те, що Міжнародний кримінальний суд доповнюе національні органи кримінальної юстиції (абзац десятий преамбули та ст. 1 Статуту),

визнання державою-учасницею Статуту юрисдикції Міжнародного кримінального суду та здійснення ним функцій і повноважень на території будь-якої держави (ст. 4, п. 1 ст. 12),

- уповноваження Асамблеї державучасниць визначати Елементи злочинів та вносити до них поправки (п.1 ст. 9),

- правил судочинства (підпункт „а” п. 1 ст. 21, ст. 51), визначення покарань (положення ст.ст. 23, 77),

- фактичного поширення на громадян України дії законів іншої держави під час відбування покарання, що позбавляє їх прав, гарантованих Конституцією України (підпункт „а” п.1 ст. 103),

- покладення на прокурора, обраного членами Асамблеї держав-учасниць, повноважень щодо доведення вини обвинуваченого (п. 4 ст. 42, п.2 ст. 66 Статуту).

11 липня 2001 р. Конституційним Судом України було прийнято Висновок щодо відповідності Конституції України Римського Статуту Міжнародного кримінального суду (Висновок від 11 липня 2001 р. № 3-6/2001, справа 1-35/2001) [1], відповідно до якого останній визнаний таким, що не відповідає Конституції України в частині його положень, за якими «Міжнародний кримінальний суд... доповнюе національні органи кримінальної юстиції».

У мотивувальній частині Висновку Конституційний Суд України наголосив на тому, що згідно з Конституцією України правосуддя в Україні здійснюється тільки судами (ч.1 ст. 124), до яких належать Конституційний Суд України та суди загальної юрисдикції (ч.3 ст. 124), та вказав, зокрема, на конституційно встановлену заборону делегування функцій судів, привласнення цих функцій іншими органами чи посадовими особами (ч.1 ст. 124), а також створення надзвичайних та особливих судів (ч. 5 ст. 125).

Конституційний Суд України також звернув увагу на відмінність МКС, який до- 
повнює систему національної юрисдикції, від міжнародних судових органів, зокрема Европейського Суду з прав людини, які за своєю природою є допоміжними засобами захисту прав і свобод людини і громадянина та до яких громадяни мають право звертатися відповідно до ч.4 ст. 55 Конституції України після використання всіх національних засобів правового захисту.

Визнавши абзац десятий преамбули та ст. 1 Статуту такими, що не відповідають частинам першій, третій ст. 124 Конституції України, Конституційний Суд України рівночасно дійшов висновку про конституційність наведених вище статей Статуту, в яких конкретизується «доповнюючий національну систему правосуддя» характер Міжнародного кримінального суду, що, зокрема, на думку окремих суддів, навряд чи можна назвати логічним з огляду на те, що всі ці положення у сукупності розкривають правовий статус цього органу [10, с. 45-48]. Одним 3 питань, що були поставлені у конституційному поданні, було встановлення можливості притягнення до відповідальності за вчинення злочинів, передбачених Статутом, посадових осіб держави, яким, згідно з Конституцією України, гарантується недоторканність.

Надаючи висновок 3 цього питання, Конституційний Суд України виходив 3 того, що, відповідно до ст. 18 Конституції України, зовнішньополітична діяльність грунтується на загальновизнаних принципах і нормах міжнародного права, одним 3 яких є принцип сумлінного виконання міжнародних зобов'язань, який виник у формі міжнародно-правового звичаю «pacta sunt servanda» ще на ранніх стадіях розвитку державності, а нині дістав своє відображення у численних міжнародних договорах.

Конституційний Суд України зазначив, зокрема, що встановлення відповідальності за вчинення переважної більшості злочинів, передбачених Римським Статутом, є міжнародно-правовим зобов'язанням України відповідно до багатьох міжнародно-правових документів, які набули чинності для нашої держави (багато з них - задовго до набрання чинності Конституцією України). Це, зокрема: Конвенція про запобігання злочинові геноциду та покарання за нього від 9 грудня 1948 р.; Женевська конвенція про захист цивільного населення під час війни від 12 серпня 1949 р.; Женевська конвенція про поводження 3 військовополоненими від 12 серпня 1949 р.; Конвенція про захист культурних цінностей на випадок збройного конфлікту від 14 травня 1954 р.; Міжнародна конвенція про попередження злочину апартеїду та покарання за нього від 30 листопада 1973 р.; Конвенція проти катувань та інших жорстоких, нелюдських або таких, що принижують гідність, видів поводження та покарання від 10 грудня 1984 р.

Відповідно до Висновку КСУ, положення Конституції України щодо недоторканності окремих посадових осіб стосується лише національної юрисдикції і не можуть бути перешкодою для здійснення юрисдикції МКС щодо тих з них, які вчинили злочини, передбачені Статутом.

Слід відзначити, що встановлений Конституцією України для окремих посадових осіб імунітет не є абсолютним. У кожному випадку Конституція України передбачає спеціальні умови притягнення таких посадових осіб до відповідальності у разі наявності відповідних підстав. Згідно із Висновком КСУ, «недоторканність певної категорії посадових осіб - це не їх привілеї; вона пов'язана 3 виконанням ними важливих державних функцій, а тому, відповідно до Конституції України і міжнародно-правових зобов'язань України, не може розглядатися як гарантія їх безкарності» (п. 5 Висновку КСУ).

Крім того, відповідно до ст. 17 Римського Статуту, МКС здійснює юрисдикцію лише у випадках, коли держава, під юрисдикцією якої знаходиться злочинець, не бажає або не здатна вести слідство або порушити кримінальне переслідування належним чином. За діяння національної юрисдикції щодо осіб, винних у вчиненні найтяжчих міжнародних злочинів, Міжнародний кримінальний суд, згідно з покладеним в основу Статуту принципом компліментарності, не здійснюватиме щодо них власної юрисдикції(ст. 20 Римського Статуту).

Як зазначалося вище, у багатьох випадках, при ратифікації державами Статуту, виникали проблеми щодо відповідності поло- 


\section{Теорія, історія держави і права, конституційне право}

жень Статуту про передачу державою-учасницею громадян до Суду (п.1 ст. 89 Статуту) нормам національних конституцій, які забороняють екстрадицію громадян. Водночас слід зауважити на тому, що Римський Статут проводить розмежування понять «передача» та «видача». Так, відповідно до ст. 102 Статуту «передача» означає доставку особи державою до Суду у відповідності із Статутом, а «видача» - доставку особи однією державою до іншої у відповідності до положень міжнародного договору, конвенції або національного законодавства[2, с. 257-261; 9, с. 257 261]. На відмінності цих категорій наголосив і Конституційний Суд України при розгляді питання щодо узгодженості вказаної норми Статуту з частиною другою ст. 25 Конституції України, відповідно до якої громадянин України «не може бути вигнаний за межі України або виданий іншій державі». Такої ж думки дотримуються і вітчизняні вчені, які вказують на відсутність у Конституції, інших актах законодавства України заборони щодо передачі іiі громадян повноважному міжнародному судовому органу у зв'язку 3 можливим вчиненням ними передбачених міжнародними конвенціями злочинів.

Наголосивши на тому, що така заборона стосується лише національної, а не міжнародної юрисдикції, Конституційний Суд України зазначив, що «конституційні положення щодо заборони видачі громадян України (навіть за умови широкого тлумачення поняття «видача») не можна розглядати окремо від міжнародно-правових зобов’язань України». Зокрема, Конвенція про попередження злочину геноциду і покарання за нього 1948 р., стороною якої є Україна, передбачає можливість такої передачі громадян відповідному міжнародному суду. Такими, що не суперечать Конституції України, було визнано і положення Статуту, відповідно до яких:

Міжнародний кримінальний суд, крім Статуту, застосовує «Елементи злочинів та свої Правила процедури і доказування» (підпункт „а” п.1 ст.21 Статуту);

«Елементи злочинів» допомагають Суду в тлумаченні і застосуванні його ст.ст. 6, 7 та 8 і «приймаються більшістю в дві третини голосів членів Асамблеї держав-учасниць» (п.1 ст. 9 Статуту);

«особа, визнана Міжнародним кримінальним судом винною, може бути покарана тільки відповідно до його положень»(ст. 23 Статуту);

визначаються види покарань особам, визнаним винними у вчиненні злочинів (ст. 77 Статуту) [1].

у мотивувальній частині Висновку Конституційний Суд України послався на частину першу ст. 9 Конституції України, згідно 3 якою міжнародні договори, згода на обов'язковість яких надана Верховною Радою України, є частиною національного законодавства України. Згода на обов'язковість міжнародного договору (його ратифікація) здійснюється Верховною Радою України у формі закону, який за своєю правовою природою не відрізняється від інших законів України [15].

Отже, приєднання України до Статуту не суперечитиме вимогам ст. 75 та пп. 14, 22 частини першої ст. 92 Конституції України, відповідно до яких Верховна Рада України як єдиний орган законодавчої влади в Україні винятково законами визначає, зокрема, судоустрій, судочинство, статус суддів, засади судової експертизи, організацію і діяльність прокуратури, органів досудового слідства, органів і установ виконання покарань, діяння, які є злочинами та відповідальність за них.

Зазначимо, що аналізований Висновок КСУ, як слушно зазначається в юридичній літературі, викликав неоднакову реакцію в юридичній доктрині. Ми приєднуємось до тих вітчизняних учених, які справедливо зазначають, що визнання Конституційним Судом України МКС наднаціональною інституцією заблокувало процес приєднання України до цієї важливої міжнародної системи захисту прав людини від державного свавілля [18, с. 123].

Як зазначає О. Харитонова, висновок про «наднаціональний» характер МКС викликаний не зовсім правильним тлумаченням принципу комплементарності (додатковості), закладеного у Римський статут, що 6 доволі «гнучким» документом, який дозволяє шукати не протиріччя, а шляхи зближення між національними законодавствами 
та Статутом. Більше того, адекватне відображення у національному законодавстві та правозастосуванні міжнародно-правових норм та принципів дозволить виключити втручання МКС, який виступає гарантом їх дотримання [18, с. 123].

На думку деяких вітчизняних юристівміжнародників (Гнатовський М., Кориневич А., Кучер О.), до якої ми також приєднуємось, Конституційний Суд України, загалом правильно розглянувши інші аспекти відповідності Римського статуту Конституції України, помилково витлумачив принцип компліментарності, що призвело до надання висновку зазначеного вище змісту [4, с. 101].Цей хибний підхід частково пояснюється тим, що висновок у справі про Римський статут було надано Конституційним Судом України у період, коли не існувало жодної практики застосування принципу компліментарності власне МКС, який почав функціонувати лише у 2003 році та його тлумачень Асамблеєю держав-учасниць Римського Статуту МКС. Останні повинні братися до уваги при тлумаченні положень Римського статуту відповідно до пунктів 2 та 3 статті 31 Віденської конвенції про право міжнародних договорів від 23 травня 1969 року (що є частиною національного законодавства України) як наступна практика застосування договору та угода, досягнута щодо договору державами, які беруть у ньому участь [4, с. 101].

Як зазначають М. Гнатовський, А. Кориневич, О. Кучер, «принцип компліментарності, закріплений у Римському статуті, як такий не $\epsilon$ новим у міжнародному праві. Його метою є вирішення питання про співвідношення міжнародної та національної кримінальної юрисдикції щодо найтяжчих злочинів проти міжнародного права. Характер цих злочинів, що посягають на найважливіші цінності міжнародного співтовариства загалом, обумовлюе обов'язок усіх держав забезпечити їхнє переслідування на національному рівні, співробітничати між собою та зі спеціалізованими міжнародними судовими установами» [4, с. 101-102]. Такі зобов'язання передбачені як договірним міжнародним правом, так і загальним звичаєвим міжнародним правом, що поширю- ється на всі держави світу без винятку незалежно від їхньої участі у тому чи іншому конкретному міжнародному договорі. Відповідні норми належать до числа jus cogens (імперативних норм загального міжнародного права), а обов'язки, що з них випливають, мають характер erga omnes (тобто не перед конкретними державами, а перед усім міжнародним співтовариством загалом) [4, c. 101-102]. Таким чином, вважають учені, видається докорінно неправильно тлумачити принцип компліментарності як такий, що порушує суверенітет держави. Навпаки, його основною метою є забезпечення повної поваги до суверенітету держави та, зокрема, iї судової влади. Разом з тим, суверенітет держави згідно з міжнародним правом не $є$ абсолютним, і його обсяг у кожному конкретному випадку залежить від дотримання державою ії міжнародно-правових зобов'язань у відповідній сфері [4, с. 101-102].

На думку зазначених вище науковців, «у випадку Римського статуту йдеться про зобов'язання всіх без винятку держав світу боротися 3 найтяжчими злочинами проти міжнародного права, що порушують його основоположні імперативні норми та посягають на цінності, спільні для всього міжнародного співтовариства. Виходячи 3 максимально поважного ставлення до суверенітету держав, а також з того, що основна відповідальність у справі забезпечення міжнародного правопорядку має покладатися саме на держави, абзац десятий преамбули Римського статуту наголошуе, що МКС не замінює собою національні судові системи, а лише доповнює їх. Відповідно, принцип компліментарності спрямований на встановлення тонкого балансу між суверенітетом держав і незалежністю міжнародної судової установи та визначає ситуації, коли держава з об'єктивних чи суб'єктивних причин не виконуе свої міжнародно-правові зобов’ язання із судового переслідування винних у найтяжчих злочинах проти міжнародного права, i, внаслідок цього, випадки, коли МКС може взяти до свого провадження ту чи іншу конкретну справу» [4, с. 101].

Як уже вище зазначалось, для виконання зобов'язань за міжнародним правом 02.06.2016 р. було схвалено Закон «Про вне- 


\section{Теорія, історія держави і права, конституційне право}

сення змін до Конституції України (щодо правосуддя)» [13], відповідно до якого наша держава може визнати юрисдикцію Міжнародного кримінального суду на умовах, визначених Римським статутом Міжнародного кримінального суду. Згідно з висновком Венеціанської комісії від 26.10.2015 р. (висновок стосувався проєкту цього Закону), таке формулювання статті Конституції отримало позитивний відгук. Однак 3 незрозумілих та юридично необгрунтованих причин це положення набирає чинності через три роки 3 дня опублікування закону, тобто 3 30.06.2019 року.

Конституційний Суд України надав Висновок 25 січня 2016 року, що таке положення відповідає Конституції України [7]. Проте, вбачається, що аналіз українського законодавства та положень Римського статуту МКС дозволяє зробити висновок, що таке рішення має суто політичний характер. Однією з причин встановлення трьохрічного строку для набрання чинності зазначеним положенням, як вважають деякі фахівці, була необхідність гармонізації національного кримінального законодавства до вимог МКС. Таке твердження видається юридично необгрунтованим, зважаючи на положення Розпорядження Кабінету Міністрів України «Про затвердження плану дій 3 реалізації Національної стратегії у сфері прав людини на період до 2020 р.» №1393р від 23.11.2015 р. [14], відповідно до якого розроблення законопроекту щодо внесення змін до Кримінального кодексу України 3 метою гармонізації з нормами міжнародного гуманітарного права (зокрема щодо визначення воєнних злочинів) мала бути завершена не пізніше IV кварталу 2016 р.

За результатами аналізу виявлено певні прогалини в законодавстві, щонайменше в частині визначення воєнних злочинів. Правозахисні організації неодноразово звертали увагу на невідповідність розділу ХХ Кримінального Кодексу України (далі - КК України) «Злочини проти миру, безпеки людства та міжнародного правопорядку» нормам МГП та Римському статуту. Зокрема, у КК не передбачена відповідальність за злочини проти людяності, а його положення щодо агресії, воєнних злочинів та геноциду не в повній мірі відповідають вимогам сучасного міжнародного кримінального права.

На нагальність розв'язання цієї проблеми звернула увагу і ПАРЕ в Резолюції №2112 (2016) «Гуманітарні занепокоєння щодо людей, захоплених під час війни в Україні», відповідно до якої ПАРЕ закликає українську владу «привести своє національне законодавство, включаючи Кримінальний кодекс та Кримінально-процесуальний кодекс, у відповідність до положення міжнародного кримінального права, i, зокрема, включити положення про статус захопленої людини і визначити тортури як тяжкий злочин» [6].

Незважаючи на те, що Верховна Рада України так i не ратифікувала Римський Статут, Україна наразі визнає юрисдикцію МКС щодо розслідування злочинів геноциду, злочинів проти людяності та воєнних злочинів, скоєних в Україні під час конфлікту, на основі двох Заяв Уряду України до МКС. Так, 17 квітня 2014 р. Уряд України запропонував МКС розслідувати порушення, що ймовірно мали місце на Майдані в період з 21 листопада 2013 р. по 22 лютого 2014 р. [17].

8 вересня 2015 р. Уряд України представив другий запит до МКС про визнання юрисдикції Суду з метою судового переслідування та притягнення до відповідальності злочинців та їх співучасників, що порушили норми МГП на території України в період 3 20 лютого 2014 по теперішній момент [12].

У результаті подання зазначених вище Заяв та їх обов'язковості щодо юрисдикції Україна має подвійні зобов'язання щодо співпраці з МКС. Щодо імплементації Римського статуту основні зобов'язання України виникають відносно принципів співробітництва та компліментарності, що передбачає: зобов'язання співпрацювати 3 МКС відповідно до ч. 9 Римського Статуту та приймати відповідні законодавчі акти про співпрацю; та принцип компліментарності, який встановлює, що МКС може здійснювати юрисдикцію лише тоді, коли держави, які повинні були мати юрисдикцію в цій ситуації, справді «не бажають або не можуть» проводити розслідування або притягати винних осіб до відповідальності. Україна справді 
має юридичні зобов'язання розслідувати злочини, які підпадають під юрисдикцію МКС [11], та притягати до відповідальності за їх скоєння [4, с. 102].

Таким чином, якщо держава бажає переслідувати винних осіб та розслідувати злочини на національному, а не на міжнародному рівні - в МКС, то вона повинна забезпечити прийняття національного законодавства та процедур щодо проведення розслідувань та притягнення до відповідальності за дії, які МКС вважає злочинами. Цей загальний принцип міжнародного права втілено в Преамбулі Римського статуту, в якій йдеться про те, що це є обов'язок кожної держави притягати до відповідальності осіб, які вчинили злочин, який підпадає під дію положення Римського Статуту. Цей обов’язок виникає на основі основоположних принципів міжнародного права. Наприклад, Україна має зобов'язання переслідувати винних осіб за геноцид, катування та воєнні злочини. Україна є стороною Женевських конвенцій, які зобов’язують переслідувати за серйозні порушення норм МГП (І Женевська конвенція, ст. 49; II Женевська конвенція, ст. 50; III Женевська конвенція, ст. 129; IV Женевська конвенція, ст. 146). Крім того, Україна ратифікувала Конвенцію проти катувань та інших жорстоких, нелюдських або принижуючих гідність видів поводження та покарання та Конвенцію про запобігання злочину геноциду та покарання за нього. Ці дві конвенції зобов'язують притягувати до відповідальності за катування та геноцид відповідно.

Таким чином, Україна скористалася можливістю, наданою частиною 3 статті 12 Римського Статуту, державам, які не є учасницями Римського Статуту, передавати на розгляд МКС конкретні ситуації. Як слушно зазначає М.М. Гнатовський, Україна де-факто «стала «асоційованою учасницею» Римського статуту, оскільки надала МКС юрисдикцію щодо деяких найсерйозніших злочинів за міжнародним правом, вчинених на іï території, але не набула жодного формального статусу перед Судом та не може користуватися ні організаційними, ні процесуальними правами, що надаються Римським статутом державам, які його ратифікували.
На Україну тепер повною мірою поширюються зобов'язання щодо співпраці державучасниць із Судом, передбачені Римським статутом, що може включати передачу підозрюваних цій міжнародній установі, але без ратифікації Україна не має національного правового механізму такої передачі» [3].

Наразі ратифікувати Римський Статут МКС стає можливим, оскільки положення частини шостої статті 124 Конституції України про те, що Україна може визнати юрисдикцію МКС на умовах, визначених Римським статутом Міжнародного кримінального суду, набрали чинності 30 червня 2019 року [13] Дотепер в Україні діяла заборона на ратифікацію Римського статуту як такого, що не відповідає Конституцй Украйни в частині, що стосується положень абзацу десятого преамбули та статті 1 Статуту, за якими «Міжнародний кримінальний суд [...] доповнює національні органи кримінальної юстиції» (див. пункт 1 резолютивної частини Висновку Конституційного Суду України у справі за конституційним поданням Президента України про надання висновку щодо відповідності Конституції України Римського Статуту Міжнародного кримінального суду (справа про Римський Статут) від 11 липня 2001 року № 3-в/2001) [1].

Слід констатувати, що визнання Україною юрисдикції МКС на умовах Римського статуту засвідчили невідповідність законодавства України про кримінальну відповідальність положенням міжнародного кримінального права. Наразі КК України не передбачає кримінальної відповідальності за злочини проти людяності, за воєнні злочини, що є порушенням звичаєвого, а не договірного МГП. При цьому слід звернути увагу, що ці специфічні прогалини у вітчизняному кримінальному законодавстві України виникли не через те, що останнє перестало «встигати» за суспільно-політичним життям, а зумовлені тим, що від моменту прийняття КК його положення системно не узгоджувались 3 нормами сучасного міжнародного права та тенденціями його імплементації в національні правові системи, в тому числі в аспекті кримінальної відповідальності за вчинення воєнних злочинів. 


\section{Теорія, історія держави і права, конституційне право}

\section{Висновки та пропозиціі}

Наразі в Україні немає єдності думок щодо необхідності ратифікації Статуту МКС. Така ситуація, на нашу думку, не сприяє однозначному усвідомленню необхідності приведення чинного кримінального, кримінально-процесуального законодавства у відповідність 3 нормами міжнародного гуманітарного та міжнародного кримінального права. Вбачається, що такі зміни повинні відбуватись без прив'язки щодо прийняття рішення про ратифікацію Статуту МКС. Разом $з$ тим, слід констатувати, що ратифікація Статуту МКС передбачає насамперед застосування комплексного підходу та повинна супроводжуватись відповідними змінами до кримінального, кримінального процесуального законодавства та інших галузей національного законодавства.

Приведення положень законодавства України щодо кримінальної відповідальності у відповідність з вимогами міжнародного кримінального права та МГП, а також практикою їх імплементації в національну правову систему вимагає більш масштабних та глибинних змін. Видається, що саме навколо цього завдання і мають бути сконсолідовані спільні зусилля всіх гілок державної влади в Україні.

\section{Лiтература}

1. Висновок Конституційного Суду України у справі за конституційним поданням Президента України про надання висновку щодо відповідності Конституції України Римського Статуту Міжнародного кримінального суду (справа про Римський Статут) від 11.07.2001 № 3-в/2001. URL: https:// zakon.rada.gov.ua/rada/show/v003v710-01

2. Вихрист С. До визначення екстрадиції. Украйнський часопис міжнародного права. 2001. №1. C. 57-60.

3. Гнатовський М. Україна та Міжнародний Кримінальний Суд: конституційний аспект. URL: https://voxukraine.org/uk/ ukraine-and-the-international-criminal-courta-constitutional-matter-ua/

4. Гнатовський М., Кориневич А., Кучер О. Міжнародний кримінальний суд: ефективність функціонування та переваги для України. Украӥнський часопис міжнарод- ного права №4/2014. С. 98-108.

5. Грищенко К.І. Міжнародний кримінальний суд -універсальний механізм міжнародного карного правосуддя / К.І. Грищенко. Украйнський часопис міжнародного права. 2003. №4. C. 9-13.

6. Гуманітарні занепокоєння щодо людей, захоплених під час війни в Україні: Резолюція Парламентської Асамблеї Ради Европи №2112 (2016). URL: http://w1.cl.rada. gov.ua/pls/mpz2/docs/2264_rez_2112.htm

7. Конституційний Суд України ухвалив висновок у справі стосовно правосуддя (22 січня 2016 року) URL: www.ccu.gov.ua/uk/ publish/article/299427

8. Лукашук И.И., Наумов А.В. Выдача обвиняемых и осужденных в международном уголовном праве. М.: Рос. юрид. издат Дом, 1998. 160 c.

9. Ляхов Е.Г. Інститут выдачи и борьба с международным терроризмом. Московский журнал международного права. 1998. № 2.C. 257-261.

10. Окрема думка суддів Конституційного Суду України Іващенка В.I. та Селівона М.Ф. стосовно Висновку Конституційного Суду України у справі за конституційним поданням Президента України о надання висновку щодо відповідності Конституції України Римського Статуту Міжнародного кримінального суду /справа про Римський Статут. Вісник Конституційного Суду Украйни. 2001. № 4. C.45-48.

11. Подані до МКС Заяви «no cymi» не зобов'язують Україну переслідувати осіб за вчинення злочинів геноциду, злочинів проти людяності або воєнні злочини на національному рівні. Проте міжнародне право змушує держави переслідувати за скоєння злочинів, які підпадають під юрисдикцію МКС, та розслідувати їх. Відомий юрист Теодор Мерон припускає, що на основі Преамбули до Римського статуту, Женевських конвенцій та інших конвенцій виникає обов'язок розслідувати злочини, які підпадають під юрисдикцію МКС, та притягати до відповідальності за їх скоєння (Theodor Meron, The Making of International Criminal Justice: A View from the Bench: Selected Speeches (OUP, 2011, p. 173).

12. Постанова Верховної Ради України 


\begin{tabular}{|c|}
\hline 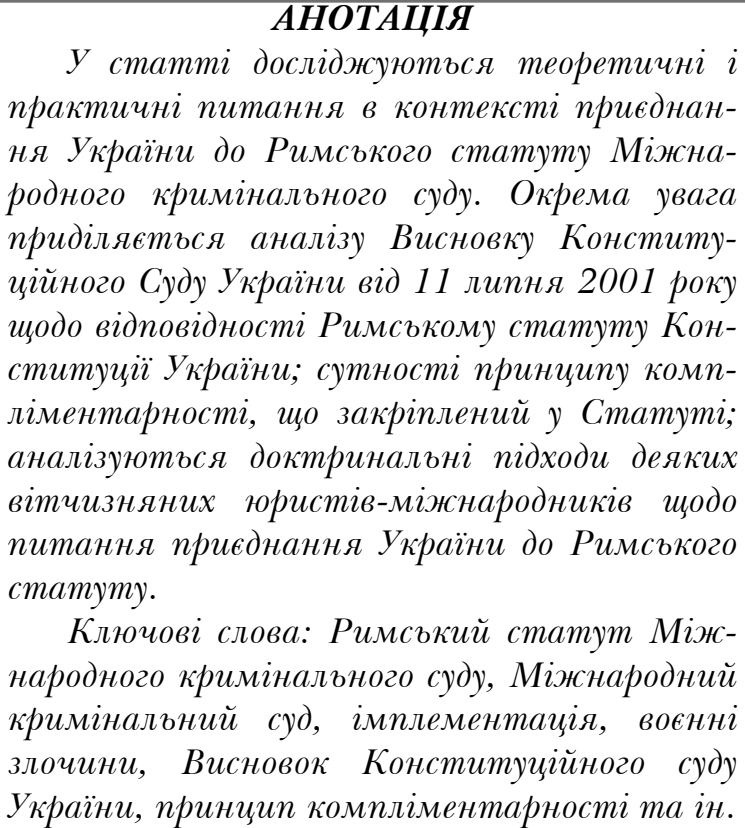 \\
\hline
\end{tabular}

«Про визнання Україною юрисдикції Міжнародного кримінального суду щодо скоєння злочинів проти людяності та воєнних злочинів вищими посадовими особами Російської Федерації та керівниками терористичних організацій «ДНР» та «ЛНР», які призвели до особливо тяжких наслідків та масового вбивства українських громадян» URL: www.icc-cpi.int/iccdocs/other/Ukraine Art_12-3_declaration_08092015.pdf.

13. Про внесення змін до Конституції України (щодо правосуддя): Закон України від 02.06.2016 року. URL: http://zakon.rada. gov.ua/laws/show/1401-19

14. Про затвердження плану дій 3 реалізації Національної стратегії у сфері прав людини на період до 2020 р.: Розпорядження Кабінету Міністрів України №1393-р від 23.11.2015 p. URL: https://www.kmu.gov.ua/ ua/npas/248740679

15. Рішення Конституційного Суду України від 12 липня 2000 р. № 9 - рп / 2000 у справі за конституційним поданням 54 народних депутатів України щодо відповідності Конституції України (конституційності) Закону України «Про ратифікацію Европейської Хартії про мови», 1992 р. Вісник
Конституиійного Суду України. 2000. №3.C. 5-9.

16. Угода про асоціацію між Україною, 3 однієї сторони, та Европейським Союзом, Европейським співтовариством 3 атомної енергії і їхніми державами-членами, з іншої [...]: від 27.06.2014. URL: https://zakon3.rada. gov.ua/laws/show/984_011

17. Уряд України подав заяву відповідно до ст. 12 (3) Римського статуту про визнання юрисдикції МКС щодо ймовірних злочинів, скоєних на території України з 21 листопада 2013 року по 22 лютого 2014 року. Ця заява була зроблена незважаючи на те, що Україна не є членом MКС. URL: www.icccpi.int/en_menus/icc/press\%20and\%20media/ press\%20releases/Documents/997/declarationR ecognitionJuristiction09-04-2014.pdf.

18. Харитонова О. Римський статут i Міжнародний кримінальний суд в контексті сучасних світових та українських кримінально-правових наукових тенденцій. Українький часопис міжнародного права. №4/2014. C. 122-124.

\section{Pylypenko V.P. \\ ON ACGESSION OF UKRAINE TO THE ROME STATUTE OF THE INTERNATIONAL CRIMINAL COURT: THEORETICAL AND PRACTICAL ASPECTS}

The author examines theoretical and practical problems of Ukraine's accession to the Rome Statute of the International Criminal Court. Special attention is paid to the analysis of the Constitutional Court of Ukraine Opinion of July 11, 2001 on the compliance of the Rome Statute with the Constitution of Ukraine; the essence of the principle of complementarity, enshrined in the Charter; the doctrinal approaches of some domestic international lawyers on the accession of Ukraine to the Rome Statute are analyzed.

Keywords: Rome Statute of the International Criminal Court, International Criminal Court, implementation, war crimes, Conclusion of the Constitutional Court of Ukraine, principle of complementarity, etc. 